Western University Scholarship@Western

Centre for the Study of International Economic Centre for the Study of International Economic

Relations Working Papers

Relations

1986

\title{
Fiscal Deficits, International Trade and Welfare
}

Joel Fried

Peter Howitt

Follow this and additional works at: https://ir.lib.uwo.ca/economicscsier_wp

Part of the Economics Commons

Citation of this paper:

Fried, Joel, Peter Howitt. "Fiscal Deficits, International Trade and Welfare." Centre for the Study of International Economic Relations Working Papers, 8617C. London, ON: Department of Economics, University of Western Ontario (1986). 
ISSN $\quad 0228-4235$

ISBN $\quad 0-7714-0755-\epsilon$

THE CENTRE FOR THE STUDY OF INTERNATIONAL ECONOMIC RELATIONS

WORKING PAPER NO. $8617 \mathrm{C}$

FISCAL DEFICITS, INTERNATIONAL TRADE AND WELFARE

\author{
Joel Fried \\ and \\ Peter Howitt
}

This paper contains preliminary findings from research work still in progress and should not be quoted without prior approval of the authors.

DEPARTMENT OF ECONOMICS

THE UNIVERSITY OF WESTERN ONTARIO

LONDON, CANADA

N6A 5C 2
Department of Economics Library

JUL 81986

University of Western Ontario 
FISCAL DEFICITS, INTERNATIONAL TRADE AND WELFARE

By Joel Fried and Peter Howitt

University of Western Ontario

July 1986

Abstract

The effects of fiscal deficits on welfare, interest rates and the balance of payments are examined in an open-economy overlapping-generations model. A deficit reduces welfare of the current foreign and domestic old and domestic unborn. The foreign unborn gain while the current foreign young may gain or lose. Long-term interest rates rise but the current short rate may rise or fall. The home country's current account will be negative the period following the deficit because of an international distribution effect. Anticipated future deficits decrease current welfare and decrease short-term interest rates but increase long rates.

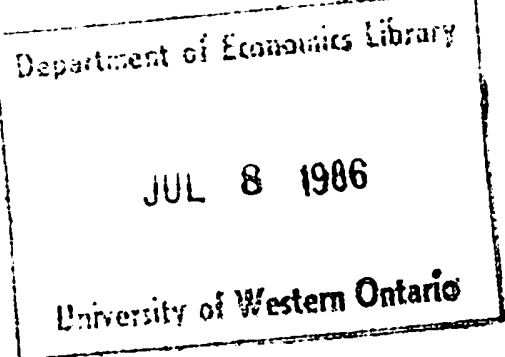




\section{FISCAL DEFICITS, IATERWATIOWAL TRADE AND WELFARE}

\section{by Joel Fried and Peter Howitt}

\section{IATRODUCTIOA}

Many observers of events in the early 1980 s attributed high real interest rates throughout the world, and large current account deficits in the United States, to the large fiscal deficits of the U.S. government, both actual and anticipated. Several economists argued that the fiscal deficits were damaging the long-run economic welfare of the United States. The adverse reaction by European politicians and central bankers implies a belief that the deficits also imposed welfare losses abroad.

The purpose of this paper is to subject these opinions to logical scrutiny by examining the effects of fiscal deficits on interest rates, asset prices, international payment accounts, and the welfare of domestic and foreign residents, in a simple overlapping generations model of the world economy. This model abstracts from short-run aggregate-demand effects of fiscal policy by assuming continuous market clearing and perfect foresight. But its explicit treatment of intergenerational differences allows it to focus on what may be the most important dimension of the welfare effects of fiscal deficits. The paper supplements the traditional literature on the burden of the national debt by asking how the debt affects the distribution of welfare not just across generations but also across nations. 
Diamond's 1965 paper was the first to address the question of the burden of the debt using the overlapping generations framework. In it he assumed reproducible capital that is perfectly substitutable in production for the single consumption good. Persson (1985) extended the Diamond analysis to an open economy, and also used these assumptions about capital. The advantage of assuming reproducible capital is that it allows one of the most commonly discussed effects of the national debt to be modeled; namely the effect on long-run capital accumulation. But the assumption that capital is perfectly substitutable in production for the consumption good rules out another equally important effect; the capital gains and losses inflicted on asset holders when interest rates change.

In this paper we abstract from capital accumulation and examine this second channel by which debt affects welfare, by supposing capital is fixed in supply: the capital in our model is best interpreted as land. ${ }^{1}$ Government $^{-1}$ debt acts as a substitute for land in agents' portfolios. It thereby affects asset prices and interest rates, which in turn affect consumption and welfare.

It turns out that allowing the price of capital to vary endogenously produces results about interest rates and welfare that are missing from Diamond's one-sector analysis. For instance, we find that, in the transition to a higher level of debt, short-term interest rates can rise or fall; in Diamond's analysis an increase in government debt causes the rate of interest to rise monotonically to its new equilibrium level. Our assumption also implies that anticipations of future government deficits will alter interest rates. In models where capital is a perfect substitute in production for consumption, fiscal deficits have no affect until they are incurred because the generation that is young the period before is not affected. The fact that interest rates will be affected in the future does not change the price it 
will receive for the capital it is now acquiring, and hence does not affect its behavior.

The differences in the effect of a fiscal deficit on welfare using the two alternative assumptions about capital are most evident in an open economy. For instance we find that, in the long run, deficits benefit foreign residents by increasing the rate of interest at which they can save when young. Persson found that they hurt foreign residents by reducing the capital intensity, thus lowering the equilibrium real wage of the young. Thus it seems that in more general models that include both reproducible and nonreproducible capital the effect can go either way. We also find that deficits harm the old in both countries who suffer capital losses on assets held at the time of the fiscal deficit. No such effects are found in Persson's model, but it seems that in this case our results are quite general for they just require capital losses to be possible and for deficits to lower asset prices. 2

\section{DEBT IN THE CLOSED ECONOMY}

\section{Basics}

We begin the analysis with a closed economy. Output is produced by the technology:

$$
y_{t}=f\left(k_{t}\right), f^{\prime}>0, f^{\prime \prime}<0 \text {, }
$$

where $y_{t}$ is output per worker and $k_{t}$ is the land-labour ratio. Assume that $k_{t}$ $=k$ for all $t$. Given fixed factors, the rental rate on land and the wage rate are, respectively:

$$
\theta=f^{\prime}(k), w=f(k)-f^{\prime}(k) k=y-\theta k .
$$

There is a population of constant size. Each individual lives two periods. An individual of generation $t$ is young in period $t$. When young he supplies one unit of labour, consumes $c_{t}$ units of output, and receives a 
transfer of $T_{t}$. With his savings he purchases assets that he sells in his second period to purchase consumption goods of the amount $x_{t+1}$. The assets are titles to land and government debt. A unit of government debt is a promise to pay $\theta$ units of the consumption good each period forever, beginning the period after issue. The price of a unit of either asset is $P_{t}$. The interest factor on an asset purchased in period $t$ and sold in period $t+1$, $R_{t+1}$, is defined as

(1) $R_{t+1}=P_{t} /\left(P_{t+1}+\theta\right)=1 /\left(1+r_{t+1}\right)$

where $r_{t+1}$ is the one-period, or short term, rate of interest on an asset purchased in period $t$. The long term rate of interest is $r_{\ell, t+1}=\theta / P_{t}$. The decision problem for generation $t$ is subject to

$$
\operatorname{Max} u\left(c_{t}, x_{t+1}\right)
$$

$$
c_{t}+R_{t+1} x_{t+1}=w+T_{t} \equiv e_{t} \text {. }
$$

Assume that $u$ is strictly monotonic, with strictly convex indifference curves that don't intersect the axes, and that $c$ and $x$ are both normal goods. Then the above decision problem yields the demand functions:

(2) $c_{t}=\hat{c}\left(R_{t+1}, e_{t}\right), x_{t+1}=\hat{x}\left(R_{t+1}, e_{t}\right)$

where

(3) $\left\{\begin{array}{l}\hat{c}>0, \hat{x}>0, \\ \partial \hat{c} / \partial e>0, \partial \hat{x} / \partial e>0, \text { and (by the Slutsky Theorem) } \\ \partial \hat{x} / \partial R<-\hat{x} \partial \hat{x} / \partial e<0 .\end{array}\right.$

By the budget constraint:

(4) $\partial \hat{c} / \partial R+\partial \hat{x} / \partial R=-\hat{x}+(1-R) \partial \hat{x} / \partial R<0$ for $R \leq 1$,

and 
(5) $\partial \hat{c} / \partial e+\partial \hat{x} / \partial e=1+(1-R) \partial \hat{x} / \partial e>0$ for $R \leq 1$.

Assume the government makes no purchase of goods or services, so that changes in the debt outstanding come through transfers to, or lump sum taxes on, the young. Transfers to the young are financed by sales of bonds to the young, the interest on which is paid by raising the tax on (reducing the transfers to) future generations. Thus the experiments we conduct in altering the level of debt correspond to a transfer of taxes from the labour income of current generations to that of future generations. Let $b_{t}$ denote the number of bonds outstanding. Then $b_{t}$ must obey the government budget constraint

(6) $b_{t+1}=b_{t}+\left(\theta b_{t}+T_{t+1}\right) / P_{t+1}$.

Given an arbitrary starting date, $t_{0}$ a sequence of transfers

$\left\{T_{t}\right\}_{t=t}^{\infty}$, and an initial stock of debt $b_{t},-1$ an equilibrium is a sequence in which markets clear under perfect foresight starting at $t_{0}$. More formally, it is a sequence $\left\{P_{t}, R_{t+1}, b_{t+1}\right\}_{t=t}^{\infty}$ that satisfies the definition (1),

the government budget constraint (6), and the goods-market-clearing condition:

(7) $c_{t}+x_{t}=y$

for all $t \geq t_{0}$, with $\left(c_{t}, x_{t+1}\right)$ given by the demand functions (2) for $t \geq t_{0}$ ' and:

(8) $x_{t}=\left(P_{t}+\theta\right)\left(k+b_{t-1}\right)$

for $t=t_{0}$.

The consumption $x_{t}$ of the initial old is not given by the demand

function (2) because our definition of equilibrium does not require that generation's expectations be fulfilled. According to (8) unexpected movements 
in $P_{t_{0}}$ confer capital gains or losses on the initial old.

In equilibrium (8) also holds for all $t>t_{0}$, and by Walras' Law the asset-market-clearing condition:

(9) $w+T_{t}-c\left(R_{t+1}, w+T_{t}\right)-P_{t}\left(k+b_{t}\right)=0$

holds for all $t \geq t_{0}$.

A stationary equilibrium is one in which the stock of bonds is held constant at its initial level by a constant tax: $T=-b \theta$, the price and interest factor are constant ${ }^{3}$ and satisfy: $P=\theta R /(1-R)$, and the consumption vector $(c, x)$ in each period, including the initial period, is given by (2). Appendix A shows that, under the assumptions given so far, for all values of $b$ in the interval $(0, w / \theta)$ there exists a unique stationary equilibrium with $0<$ $\mathbf{R}<1$.

The conceptual experiment by which we investigate the effects of deficits is the following. Suppose the economy before period 1 is in a stationary equilibrium with no government debt and no transfers. In period 1 the government unexpectedly makes a positive transfer $T_{1}$ to the young of generation 1. This requires the government to issue the amount $b=T_{1} / P_{1}$ of debt. In all future periods the debt will be held constant at the level b, by a tax equal to $\theta b$. So starting in period 2 the economy will be in a new stationary equilibrium, after a single period of transition. After the initial transfer that created the deficit there will be no more surprises, ${ }^{4}$ so the economy will be in an undisturbed equilibrium from period 1 forward. 5 


\section{The long-run effects of deficits}

The interest factor in a stationary equilibrium is given by the function $R(b)$ that solves the goods-market-clearing condition:

$$
D(R ; b) \equiv \hat{c}(R, w-\theta b)+\hat{x}(R, w-\theta b)-y=0 \text {. }
$$

Appendix A shows that for all $b$ in the interval $(0, w / \theta), R(b)$ satisfies:

(11) $-\theta / \hat{x}(R, w-\theta b)<R^{\prime}(b)<0$.

From this and (1) it follows that the long-run effect of the deficit is to raise the rate of interest and reduce the price of assets. That is:

$$
R_{3}<R_{1} \text {, and } P_{2}<P_{0} \text {. }
$$

where $R_{1}=R(0)$ and $R_{3}=R(b)$ are the interest factors prevailing before and after the deficit of period 1 , and where $P_{0}$ and $P_{2}$ are the corresponding stationary-equilibrium asset-prices. The economic interpretation of this result is that the increase in taxes to pay the interest on the debt depresses aggregate demand, and the rise in the rate of interest brings it back up to the full-employment level.

To examine the effects of the deficit on the welfare of an individual in the stationary state, construct the indirect utility function:

$$
\begin{aligned}
V(R, e) & =\operatorname{Max} u(c, x), \text { s.t. } c+R x=e \\
& =u(\hat{c}(R, e), \hat{x}(R, e)),
\end{aligned}
$$

and let

$$
\psi(b)=V(R(b), w-\theta b) .
$$

Thus $\Psi(b)$ shows the stationary-state utility level as a function of the outstanding debt.

Debt affects utility by raising taxes and by raising the rate of interest. The following argument shows that the tax effect dominates, so that the deficit reduces stationary-state utility. From Roy's Lemma, 


$$
v_{1}=-x v_{2}<0,
$$

we get

$$
\Psi^{\prime}(b)=V_{1} R^{\prime}(b)-V_{2} \theta=-V_{2}\left\{x R^{\prime}(b)+\theta\right\} .
$$

Because $v_{2}$ is positive and, by (11), the term in braces is also positive, therefore $\Psi^{\prime}(b)<0$.

Stationary equilibria are illustrated in Figure 1. The equilibrium with no debt is at $A$, where the individual's optimum lies on the equilibrium locus, yy. Because $R<1$ this locus is steeper than the budget line. The equilibrium with debt is at B. The reason why B lies to the southeast of $A$ along the equilibrium locus rather than to the northwest is that, because c and $x$ are both normal, the slopes of successive indifference curves decrease as you move to the southeast. It follows immediately that:

$$
\text { If } \hat{x}(R, e) \leq \hat{x}(R, e) \text { and } \hat{c}\left(R_{i}, e\right) \geq \hat{c}{ }_{i} \underline{e}_{j}, e, j, \text { with at least one }
$$

strict inequality, then $R>R \mathbf{~}_{j}$.

This proposition will be used below in several places; we call it the Normality Proposition. In terms of Figure 1 it implies that B cannot lie to the northwest of $A$ for this would require $R(b)>R(0)$, which we know is false.

This argument establishes that the long-run effect of the deficit is to increase consumption of the old and reduce consumption of the young:

$$
x_{2}>x_{0}, c_{2}<c_{0}
$$

where $\left(c_{0}, x_{0}\right)$ and $\left(c_{2}, x_{2}\right)$ are the stationary-equilibrium consurption vectors before and after the deficit. 
9

Figure 1: The long-term effects of debt in the closed economy

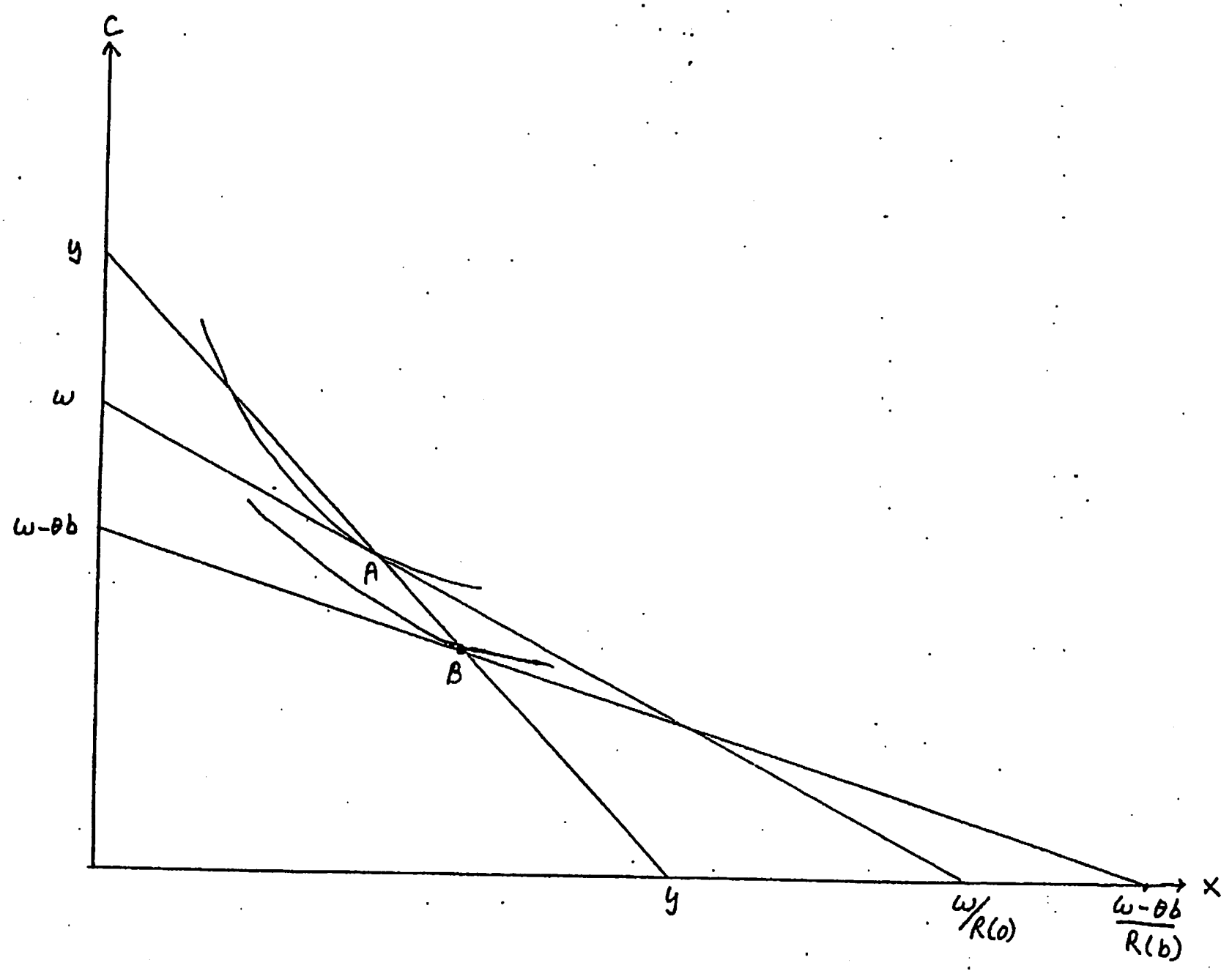




\section{The short-run effects of deficits}

In the transition period $(t=1)$ the asset-market-clearing condition ( 9 ) must be satisfied with $T_{1}=P_{1} b_{,} b_{0}=0$, and $R_{2}=P_{1} /\left(P_{2}+\theta\right)$. The goods-market-clearing condition for period 2 is:

$$
\hat{c}\left(R_{3}, w-\theta b\right)+\hat{x}\left(R_{2}, w+T\right)=y .
$$

During the transition the short-term interest rate will be less than in the new stationary equilibrium:

$$
R_{2}>R_{3}
$$

This is because in order for the goods market to clear in period 2 at the new stationary-equilibrium rate of interest the consumption of generation 1 , $\hat{x}\left(R_{2}, w+T_{1}\right)$, must equal the new stationary-equilibrium value, $\hat{x}(\xi, w-\theta b)$, which implies $R_{2}>R_{3}$ because $x$ is a normal good and because $\partial x / \partial R<0$. However, $R_{2}$ can be more or less than the initial interest factor $R_{1}$. This can be seen with the aid of Figure 2, where $A$ and $B$ are the initial and final stationary equilibria. Because the economy will be in a stationary equilibrium in period 2 , therefore the consumption vector $\left(c_{1}, x_{2}\right)$ of generation 1 must lie on the vertical line through $B$. Hold b constant at its new post-deficit value and set $P_{1}$ equal to the value $P_{1}^{\prime} \equiv R_{1}\left(P_{2}+\theta\right)$ that keeps the interest factor constant at $R_{1}$. Then generation 1 will face a budget line parallel to that of the initial stationary equilibrium, and will choose point D. If, as in Figure 2, D lies to the right of $C$, the point on the new budget line vertically above $B$, then in order to induce generation 1 to locate vertically above $B$ the equilibrium price of assets must be set higher than $P_{1}^{\prime}$ (a reduction in $P_{1}$ would raise $x_{2}$ even further ${ }^{6}$ ). Because $P_{1} \equiv R_{2}\left(P_{2}+\theta\right)$, 
Figure 2: The short-term rate can rise or fall during the transition

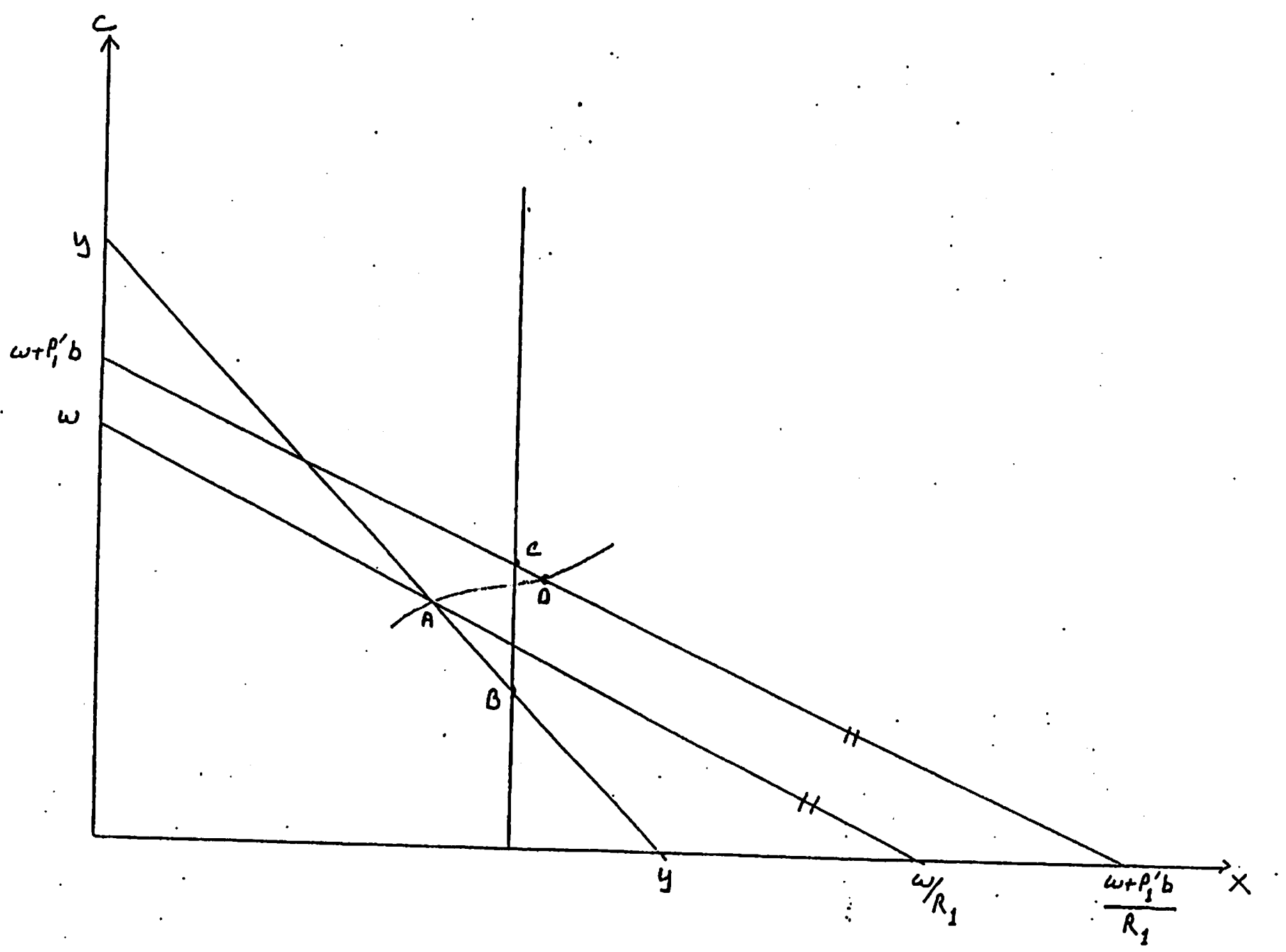


therefore $R_{2}$ must exceed $R_{1}$. Similarly, if $D$ lies to the left of $C$ then $R_{2}$ must be less than $R_{1}$.

Although the short term rate of interest can rise or fall initially, the long-term rate rises monotonically through the transition, that is:

$$
P_{2}<P_{1}<P_{0}
$$

That $P_{2}<P_{1}$ follows automatically from (1) and the fact that $R_{3}<R_{2}$. That $P_{1}<P_{0}$ can be demonstrated by the following reductio ad absurdum. Suppose, on the contrary, that $P_{1} \geq P_{0}$. Then, by (8), $x_{1} \geq x_{0}$. So, by the goods-market-clearing condition, $c_{1} \leq c_{0}$. This, together with the fact that $x_{2}>x_{0}$ implies:

$$
\hat{x}\left(R_{1}, w\right)<\hat{x}\left(R_{2}, w+P_{1} b\right) \text { and } \hat{c}\left(R_{1}, w\right) \geq \hat{c}\left(R_{2}, w+P_{1} b\right)
$$

which by the Normality Proposition implies $R_{1}>R_{2}$. But this implies a contradiction, because $P_{1} \geq P_{0}$ and $P_{2}<P_{0}$ imply:

$$
R_{2}=\frac{P_{1}}{P_{2}+\theta} \geq \frac{P_{0}}{P_{2}+\theta}>\frac{P_{0}}{P_{0}+\theta}=R_{1} .
$$

The effects on the welfare of those generations alive in period 1 are straightforward. The deficit increases the welfare of generation 1 because it allows that generation to consume more in each period than if the original stationary equilibrium had been left undisturbed. ${ }^{7}$ Because the deficit is unanticipated it does not affect the consumption of generation 0 when young But it reduces their consumption when old by inducing an unexpected capital loss: $x_{1}-x_{0}=P_{1} k-P_{0} k<0$. Thus it reduces the welfare of generation 0 . 
The assumption of a fixed capital stock generates different implications than those of Diamond's one sector reproducible capital model. In our analysis the initial old unambiguously lose, while in Diamond's model they are unaffected. This is because his model precludes capital losses. Both models however predict a decrease in welfare for generations in the new steady state, and an increase in welfare for the initial young.

Our model also yields different results concerning the short term rate of interest. In Diamond's model $R_{t}$ falls monotonically from $R_{1}$ to the new stationary-equilibrium value. In our model it is possible for $R_{2}$ to exceed $R_{1}$, which exceeds $R_{3}$.

When the economy is opened to trade in goods and asset titles with other countries, further differences arise from the nature of the assumptions about capital. We now examine the open economy case.

\section{THE OPEN ECOLOHY}

\section{Equilibrium}

In this section we postulate a second country, which is also populated by overlapping generations of identical agents. A symbol $z^{*}$ represents the foreign equivalent of the home country symbol z. Tastes, technology, and relative endowments of labour and land may differ between the two countries. Per worker output in the foreign country is $y^{*}=f^{*}\left(k^{*}\right)$. The ratio of foreign to domestic population is $\lambda$. For notational simplicity $k^{*}$ is measured in units such that $f^{* \prime}=\theta$. Assume that $b_{t}^{*}=0$ for all $t$.

There is free international movement of goods and assets. There is no possibility of reneging or defaulting on the promised income from ownership of $k, k^{*}$, or government debt. Lump sum taxes can be collected only from the 
young of the country whose government has levied the taxes. Thus the price of assets, and the interest factor, will be common to both countries. These are designated $P_{t}^{*}$ and $R_{t}^{*}$ to indicate that they are determined by the world economy. For expositional purposes suppose that, at $t<1, R_{t}^{*}$ is equal to $R(0)$; that is, in the experiments that we conduct, the initial conditions are such that the trade balance in each country is zero.

The foreigners' decision problem yields demand functions, $\hat{c}_{t+1}^{*}\left(R_{t}^{*}, e^{*}\right)$ and $\hat{x}^{*}\left(R_{t+1}^{*}, e_{t}^{*}\right)$, with the properties (3). Aggregate demands are denoted:

$\hat{c}\left(R_{t+1}^{*}, e_{t}, e_{t}^{*} ; \lambda\right) \equiv \hat{c}\left(R_{t+1}^{*}, e_{t}\right)+\lambda \hat{c}^{*}\left(R_{t+1}^{*}, e_{t}^{*}\right)$, and $\left.\dot{x}\left(R_{t+1}^{*}, e_{t}, e_{t}^{*} ; \lambda\right) \equiv \underset{t+1}{\hat{x}\left(R^{*}\right.}, e_{t}\right)+\lambda \hat{x}^{*}\left(R_{t+1}^{*}, e_{t}^{*}\right)$.

We begin the analysis in a stationary equilibrium with no debt in either country. In period 1 the domestic government unexpectedly incurs a deficit to finance a transfer to generation 1 . From period 2 on, the world economy will be in a stationary equilibrium with a constant tax in the home country.

The goods-market-clearing condition is:

$$
c_{t}+x_{t} \equiv c_{t}+\lambda c_{t}^{*}+x_{t}+\lambda x_{t}^{*}=y+\lambda y^{*} \text {. }
$$

and the asset-market-clearing condition is:

$$
w+T_{t}+\lambda w^{*}-C_{t}-P_{t}^{*}\left(k+\lambda k^{*}+b_{t}\right)=0
$$

Global consumption of the old each period must equal the value of their assets: (12) $\left.x_{t}+\underset{t}{\lambda x^{*}}=\underset{t}{\left(P^{*}\right.}+\theta\right)\left(k+\lambda k^{*}+b_{t-1}\right) ; t \geq 1$

Furthermore, in periods 0 and 1 the consumption of the old will be: 


$$
x_{t}=\left(P_{t}^{*}+\theta\right) k, x_{t}^{*}=\left(P_{t}^{*}+\theta\right) k^{*} ; t=0,1
$$

In order for the goods market to clear in the second period then the global consumption of the old of generation 1 must be the same as in the new stationary equilibrium:

(13) $x_{2}+\lambda x_{2}^{*}=\hat{x}\left(R_{2}^{*}, w+P_{1}^{*} b, w^{*} ; \lambda\right)=\hat{x}\left(R_{3}^{*}, w-\theta b, w^{*} ; \lambda\right)$.

The condition defining a stationary equilibrium is:

$$
\begin{aligned}
D\left(R^{*} ; b\right)= & C\left(R^{*}, w-\theta b, w^{*} ; \lambda\right)+X\left(R^{*}, w-\theta b, w^{*} ; \lambda\right) \\
& -\left(y+\lambda y^{*}\right)=0
\end{aligned}
$$

As in the closed economy case, for any $b \in[0, w / \theta)$ there is a unique stationary equilibrium with $R^{*} \in(0,1)$.

\section{Lons-run effects}

The long-run effect of the deficit is to increase the rate of interest, because, according to (14), (4), (5) and the fact that $0<R^{\star}<1$ :

(15) $R^{*}(b)=\frac{\partial \hat{c} / \partial e+\partial \hat{x} / \partial e}{\partial \hat{c} / \partial R^{*}+\partial \hat{x} / \partial R^{*}+\lambda\left(\partial \hat{c} * / \partial R^{*}+\partial \hat{x} * / \partial R^{*}\right)}<0$.

As in the closed economy:

(16)

$$
-\theta / \hat{x}\left(R^{*}(b), w-\theta b\right)<R^{*}(b)
$$

and :

$$
\mathrm{R}_{3}^{*}<\mathrm{R}_{1}^{*} \text {, and } \mathrm{P}_{2}^{*}<\mathrm{P}_{0}^{*} \text {. }
$$

In the long run the deficit will increase the consumption of the old in the foreign country, because $\hat{x}^{*}\left(R^{*}, w^{*}\right)$ is a decreasing function of $R^{\star}$. It 
will have an ambiguous effect on consumption of the foreign young, but total foreign consumption: $\hat{c} *\left(R^{*}, \omega\right)+\hat{x}^{*}\left(R^{*}, w\right)$ will be increased because by (4) this total is a decreasing function of $R^{*}$.

Because total foreign consumption goes up, goods-market-clearing requires total domestic consumption to go down. This means that domestic consumption of the young, $c_{2}$ must be decreased, for otherwise the Normality Proposition would be violated.

The long-run effects on welfare are straightforward. The welfare of future generations in the foreign country is unambiguously improved because of the rise in interest rates. (Their utility level is $V^{*}\left[R^{*}(b), w^{*}\right]$ and $v_{1}^{*}<$ 0.) The welfare of future generations in the domestic country is unambiguously reduced because, as in the closed-economy case, the income-effect of taxes outweighs the favourable effect of the rise in the rate of interest. 8

The long-run welfare effect in the foreign country differs from Persson's result, which had foreign welfare fall in tandem with domestic welfare. The difference is explained by the additional effect in his model of the fall in capital and the real wage. With land instead of capital no such effect occurs in our model.

\section{Short-run effects}

We now turn to the transitional effects of the deficit. During the transition the short-term rate of interest will be lower than it will be in the new stationary equilibrium:

$$
\mathbf{R}_{3}^{*}<\mathbf{R}_{2}^{*}
$$

This follows from the second equality in (13) and the fact that $\hat{z}$ is increasing in $e_{t}$ and decreasing in $R_{t}^{*}$. 
As before, it follows directly that the long-term rate of interest will be lower in the transition than in the new stationary equilibrium:

$$
\mathbf{P}_{2}^{*}<\mathbf{P}_{1}^{*}
$$

However, it is not possible without further assumptions to show that $\mathrm{P}_{1}^{*}<\mathrm{P}_{0}^{*}$. During the transition the long rate could actually fall below its initial stationary equilibrium value.

It turns out that this perverse effect on the long rate can occur only if saving is negatively affected by the rate of interest. From here on we shall rule out this possibility, with the assumption that:

(17) $\frac{\partial \hat{c}}{\partial R^{*}}>0, \frac{\partial \hat{c}^{*}}{\partial R^{*}}>0$.

That $P_{1}^{*}<P_{0}^{*}$ can now be shown by the following reductio ad absurdum. Suppose, on contrary, that $P_{1}^{*} \geq P_{0}^{*}$. Then because $P_{2}^{*}<P_{0}^{*}$, therefore $R_{2}^{*}>R_{1}^{*}$. It follows from this and (17) that $c_{1}^{*}>c_{0}^{*}$; likewise, since in addition the domestic generation 1 receives a transfer unavailable to generation $0, c_{1}>c_{0}$. Therefore, by goods-market clearing, $x_{1}-x_{0}=c_{0}-c_{1}<$ 0. But, by (12), $x_{1}-x_{0}=\left(P_{1}^{*}-P_{0}^{*}\right)\left(k+\lambda k^{*}\right)$; therefore $P_{1}^{*}-P_{0}^{*}<0$, a contradiction.

The deficit increases consumption of generation 1 in the home country in both youth and old age. To prove $x_{2}>x_{0}$ note that, because $R_{3}^{*}<R_{1}^{*}$ and $c$ is normal, therefore $c_{2}<c_{0}$. Therefore, by goods-market clearing:

$$
\left(x_{2}-x_{0}\right)+\lambda\left(x_{2}^{*}-x_{0}^{*}\right)>0 \text {. }
$$

This inequality shows $x_{2}>x_{0}$ if $x_{2}^{*} \leq x_{0}^{*}$. If $x_{2}^{*}>x_{0}^{*}$ then $R_{2}^{*}<R_{1}^{*}$, which, together with the normality of $x$ implies $x_{2}>x_{0}$.

To prove $c_{1}>c_{0}$ note that, because $P_{1}^{*}<P_{0}^{*}$, therefore, by (12),

$x_{1}<x_{0}$. Therefore, by goods-market-clearing: 


$$
\left(c_{1}-c_{0}\right)+\lambda\left(c_{1}^{*}-c_{0}^{*}\right)>0 .
$$

This inequality shows $c_{1}>c_{0}$ if $c_{1}^{*} \leqq c_{0}^{*}$. If $c_{1}^{*}>c_{0}^{*}$ then by (17) $R_{2}^{*}>R_{1}^{*}$,

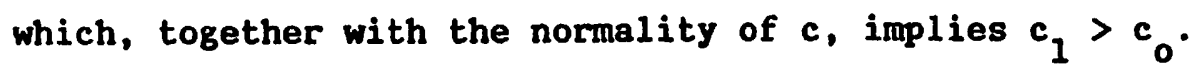

The effects of the deficit on the consumption pattern of generation 1 in the foreign country depends upon the transitional effect on the rate of interest. If $R_{2}^{*}>R_{1}^{*}$, then, by (3) and (17) this generation will consume more when young and less when old, compared with the initial equilibrium. If $R_{2}^{*}<R_{1}^{*}$ the opposite results hold.

The effects on the welfare of the transition generations are straightforward. Because the deficit results in an unanticipated decrease in asset prices therefore, as in the closed economy case, it reduces the welfare of all members of generation zero (both at home and abroad). Because it raises the consumption of generation 1 at home in both periods it raises their welfare. The effect on generation 1 abroad is $V *\left[R_{2}^{*}, w\right]-V *\left[R_{1}^{*}, w\right]$; this generation is made better off if the short-term rate of interest rises and worse off if it falls.

Again these results differ from those of a one sector reproducible capital model. The major difference is that generation 0 loses in our model because of a capital loss that cannot occur in one sector models. Another difference is that our model admits the possibility that the foreign generation 1 could lose from the fiscal deficit. One sector models preclude such an outcome, because the short-term interest rate necessarily rises in period 1 as debt crowds out capital, and the real wage is historically given by the previous capital accumulation of generation 0 . 
It is interesting to note that in one sector models the welfare conflicts are entirely between generations, not within a generation: the qualitative effect of a deficit on an individual's welfare is the same whether that individual is located at home or abroad. In our model, it matters where the agent is located; future generations in the rest of the world gain while their cohorts at home lose, and the home country young gain at the possible cost of their foreign cohorts. In other words, our model is potentially capable of explaining some of the international conflicts that could arise from fiscal policy as well as the intergenerational conflicts that play the major role in one sector models. 9

\section{Balance of payments}

In terms of $P_{t}^{*}$ and $R_{t+1}^{*}$, the transition consists only of period 1; in terms of the balance of payments accounts, however, the transition continues beyond period 1 through period 2. In particular in period 2, the home country will run a current account deficit. To see this note first that, because $R_{3}^{*}<R_{2}^{*}$, therefore saving of foreign generation 2 must be greater than of generation 1. This, together with $P_{2}^{*}<P_{1}^{*}$, means that in period 2 the foreign old will have saved fewer assets than the foreign young are going to buy. Hence, there will be a net purchase of assets from residents of the home country: that is, a capital inflow to the home country, and therefore a current account deficit. In period 3 the current account will be zero, with the (positive) trade balance equal the negative of the service account. The reason why the transition carries into period 2 is that the debt issue increases the wealth of generation 1 in the home country relative to the foreign country. This distribution effect persists for the lifetime 
of generation 1. For the closed economy no such contemporaneous distribution effect existed because all agents of generation 1 increase their wealth equally.

We can also show that under some fairly general conditions the home country's current account will be negative in period 1 . For example, if the short-term rate doesn't fall (if $R_{2}^{*} \leq R_{1}^{*}$ ) then, by (17) and the fact that $x_{1}^{*}<x_{0}^{*}:$

$$
\hat{c}_{1}^{*}+x_{1}^{*}<\hat{c}_{0}^{*}+\hat{x}_{0}^{*}=y^{*}
$$

so the foreign current account is positive. Therefore the current account in the home country is negative.

Even if the short-term rate falls $\left(R_{2}^{*}>R_{1}^{*}\right)$, the current account in period 1 will be negative if $b$ is small enough and the short-term rate is no greater than it would be if the economy were open (i.e. $R_{2}^{*} \geq R_{2}$ ). In this case $P_{2}^{*}>P_{2} \cdot 10$ Therefore $P_{1}^{*}=R_{2}^{*}\left(P_{2}^{*}+\theta\right)>R_{2}\left(P_{2}+\theta\right)=P_{1}$. The current (and trade) account balance of the home country is:

$$
\begin{aligned}
& y-c\left(R_{2}^{*}, w+P_{1}^{*} b\right)-\left(P_{1}^{*}+\theta\right) k \\
& \left.<y-\hat{c}\left(R_{2}, w+P_{1} b\right)-\left(P_{1}+\theta\right) k \text { (because } R_{2}^{*} \geq R_{2} \text { and } P_{1}^{*}>P_{1}\right) \\
& =0 \text { (from goods-market-clearing in the closed economy). }
\end{aligned}
$$

As a third case, assume all agents in the world have identical preferences, use the same production technology and have the same per capita resources. Then the debt-issuing country will also have a negative current account. This is because, by normality, $c_{1}=\hat{c}\left(R_{2}^{*}, w+P_{1}^{*} b\right)$ $>\hat{c}\left(R_{2}^{*}, W\right)=c_{1}^{*}$ and, since $x_{1}=x_{1}^{*}$, total per capita consumption is greater in 
the home country than abroad. Since, by assumption, per capita output is the same, the home country must have a negative trade and current account balance.

What we cannot show is that the current account will always be negative when $R_{1}<R_{2}^{*}<R_{2}$. In this case $c_{1}$ and $c_{1}^{*}$ will both increase while $x_{1}^{*}$ and $x_{1}$ will fall. If foreign demand for first period consumption is very sensitive to the decreased interest rate relative to home country demand, and $\partial \hat{c} / \partial e$ is low, then it appears possible that the increase in $c^{*}$

could be greater than the decrease in $x_{1}^{\star}$, generating a current account surplus in the home country.

\section{ANTICIPATED BUDGET DEFICITS}

In this section we assume that generation 0 knows in advance of the deficit in period 1 . This information could not affect $P_{1}^{\star}$ and $R_{2}^{\star}$ since the old will come to market in period 1 with precisely the same total amount of titles to land as they would have brought had they not had the information. Therefore generation 1 and subsequent generations are unaffected by the fact that the period 1 deficit was expected, and the expectation can affect only generations 0 and $(-1)$. The anticipation allows generation 0 to recognize that $x_{1}$ and $\lambda x_{1}^{*}$ will be less than initially expected. The only mechanism by which the planned demand for $x_{1}$ can be reconciled with this lowered expectation is a change in the interest factor. Therefore, by (3):

$$
R_{1}^{*}>R^{*}(0) \text {. }
$$


Furthermore, asset prices will be greater in period 0 than in period 1 , but less than they would have been if the fiscal deficit had not been anticipated in period 0 :

$$
\mathrm{P}_{1}^{*}<\mathrm{P}_{0}^{\star}<\mathrm{P}^{*}(0) \text {. }
$$

To show $\mathrm{P}_{0}^{*}<\mathrm{P}^{*}(0)$ note that, because $\mathrm{R}_{1}^{*}>\mathrm{R}^{*}(0)$, therefore

$c_{0}>\hat{c}\left(R^{*}(0), w, w^{*} ; \lambda\right)$. Therefore, by goods-market-clearing

$\left.X_{0}<X^{*}(0), w, w^{*} ; \lambda\right)$, which by $(12)$ implies $P_{0}^{*}<P^{*}(0)$. To show

$P_{1}^{*}<P_{0}^{*}$ suppose the contrary. Then $R_{1}^{*}=P_{0}^{*} /\left(P_{1}^{*}+\theta\right) \leq P_{0}^{*} /\left(P_{0}^{*}+\theta\right)$

$\left\langle\mathrm{P}^{*}(0) /\left(\mathrm{P}^{*}(0)+\theta\right)=\mathrm{R}^{*}(0)\right.$, which contradicts the earlier result that

$R_{1}^{*}>R^{*}(0)$

More generally, if the period 1 fiscal deficit is first anticipated in period $\tau, \tau \leq 0$, then

$$
\mathrm{P}_{T}^{*}>\mathrm{P}_{T+1}^{*}>\ldots>\mathrm{P}_{0}^{*}>\mathrm{P}_{1}^{*}
$$

and

$$
\mathrm{R}_{\tau+1}^{*}<\mathrm{R}_{\tau+2}^{*}<\ldots<\mathrm{R}_{0}^{*}<\mathrm{R}_{1}^{*} \cdot 11
$$

It is also the case that

$$
\mathrm{P}_{\tau}^{*}<\mathrm{P}^{*}(0)
$$

and

$$
\mathrm{R}_{\tau+1}^{*}>\mathrm{R}^{*}(0) \text {. }^{12}
$$


Anticipated fiscal deficits therefore generate somewhat surprising term-structure relationships. These are plotted in Figure 3 . Long rates, $r_{\ell, t+1}^{*}=\theta / P_{t}^{*}$, rise continuously from the time the fiscal deficit is first anticipated until the new stationary equilibrium is achieved. Short rates fall continuously from the time the deficit is anticipated until the debt is issued, before rising to equal the long rate in the new stationary equilibrium. The reason for this puzzling behaviour in short rates is simply a result of the attempt by generations 0 and earlier to minimize the consequences of the capital loss on their land holdings that will arise from the debt issue, by shifting their consumption patterns toward their youth. The short rates and asset prices adjust as they do to reconcile these new consumption patterns.

The one ambiguity in the pattern of interest rates is whether the turning point in the short rate occurs at the time of the debt issue $\left(R_{1}^{*}>\right.$ $\mathbf{R}_{2}^{*}$ ) or in the following period. Because of the distribution effect on generation 1 at home and abroad no general conclusion can be made.

Not much can be said about the balance of payments accounts in response to a future anticipated fiscal deficit because the expectations work through the same interest rate mechanism on the home and foreign generations. ${ }^{13}$ Thus depending on differences in tastes, the home country's trade balance in period $\tau$ to period 0 could be positive or negative.

Welfare effects are unambiguous however. Because the short-term rate of interest falls in period 1 relative to the previous period, generation 0 must be made worse off by the future deficit. However, they are better off than if the deficit had hit them unexpectedly, because $p_{0}^{*}$ will be less 


\section{Figure 3 The dynamic effects on long and short term interest rates of an} anticipated deficit

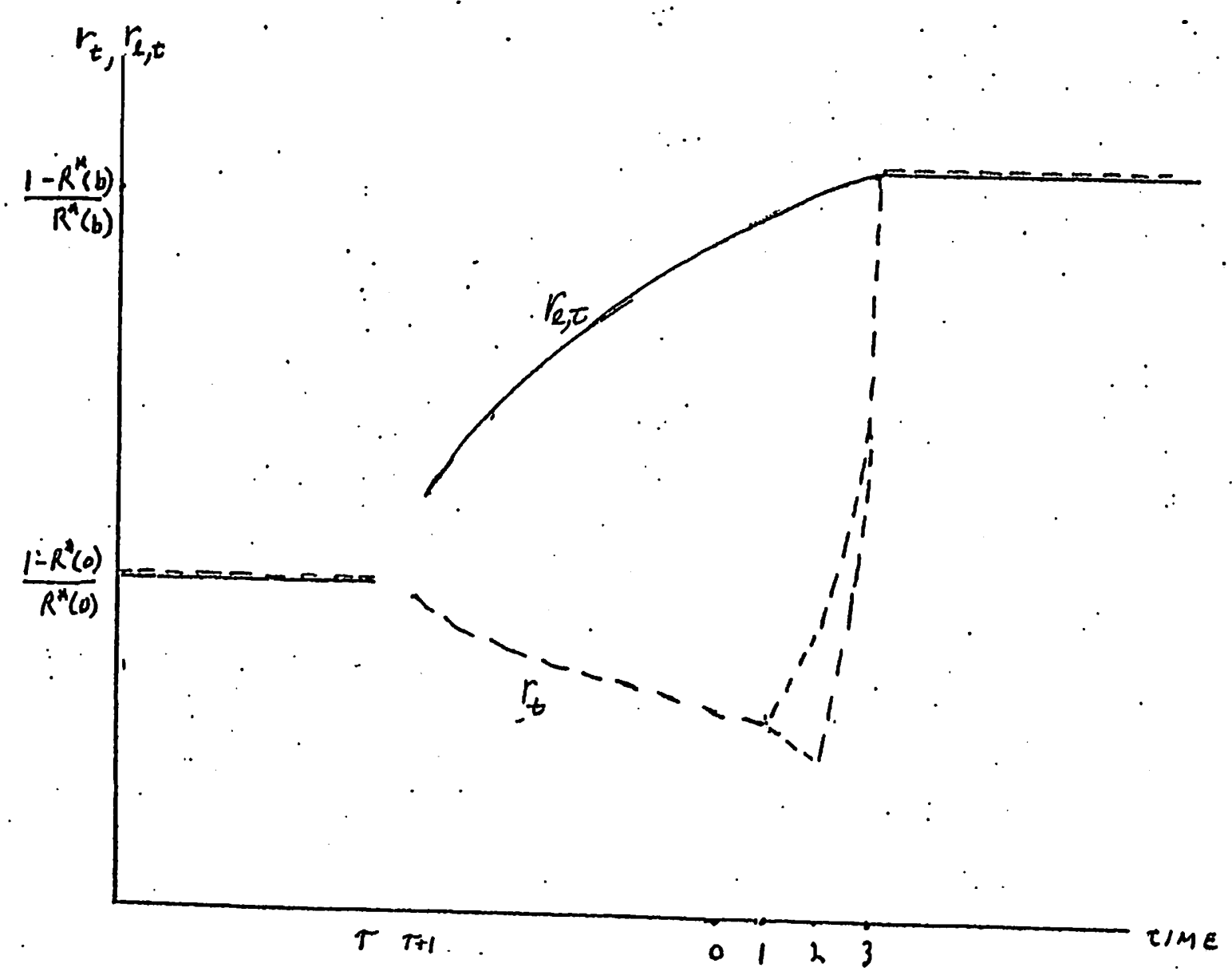


than it would have been. Thus, the consumption pattern that each individual of generation 0 would have received without the expectation of the deficit is now in his budget set. Because of the progressive fall in the short term interest rate generations $\tau$ to -1 also have decreased welfare, but the earlier the generation at home or abroad the less the welfare cost of the future deficit.

Finally, in one sector models the anticipation of fiscal deficits will not affect welfare because each generation has the ability to sell its capital at a fixed relative price of 1 . Since generation 0 is not exposed to capital gains or losses they will not change their consumption plan. Therefore neither will any earlier generation.

\section{ALTERNATIVE TECHNOLOGIES}

The implications derived in the previous sections are, in important respects, specific to the technology. Throughout the analysis we have pointed out how our implications differ from those of Diamond and Persson who use a one sector reproducible capital framework: generally speaking, the differences in modelling are such that, for the open economy, a fixed capital stock causes some generations born prior to a fiscal deficit to be adversely affected by it and secondly, gives rise to intragenerational conflicts as well as the intergenerational conflicts that occur with reproducible capital. 
To examine the robustness of modelling capital as we or Diamond/Persson have, consider another technology that requires land, labour and capital to produce a composite capital/consumption good. Land is fixed in supply and has a price $\mathrm{P}_{t}$ in terms of the capital/consumption good. An increase in debt will crowd out some of the real value of the other assets. This takes the form of a decrease in the price of land immediately and a decrease in the capital stock subsequently. The decrease in $P^{\star}$ will mean a welfare loss to the old consistent with our analysis but in contrast to Diamond and Persson. As the capital stock decreases, so too does output, making it possible that, in contrast to our analysis, future generations in the foreign country lose, However, with three factors of production, the possibility of substitutability of factors could still cause our results to hold. If, for instance, capital and labour are substitutes in production then the marginal product of labour and the real wage will rise. Because the real wage is the only element in the wealth of the foreign young, they, at least, must be made better off by the fiscal deficit. Thus either Persson's or our results concerning future generations may be valid in this broader model. Finally, as in our model anticipated fiscal deficits will continue to matter. Not only will they affect intertemporal prices but, in doing so, will also alter the capital stock and output.

The assumption that a single good is produced is also critical for any welfare conclusions. For instance suppose, as is typical in trade theory models, two consumption goods, $z_{1}$ and $z_{2}$, are produced using two inputs, labour and land, both fixed in supply. Suppose further that $z_{1}$ is labour intensive, that foreigners have a relative preference for $z_{1}$ and home country residents have a relative preference for $z_{2}$. There are no barriers to trade of goods or of titles to income streams. Then, since 
foreigners ultimately become wealthier relative to residents in the home country the price of $z_{1}$ ultimately rises relative to the price of $z_{2}$. Further, by the Stolper-Samuelson theorem, the wage increases relative to the prices of both $z_{1}$ and $z_{2}$ so the real wage has increased. As Fried (1980) has pointed out, this change in relative prices leads to an intergenerational redistribution, in this case from the old to the young. It may be possible that this intergenerational redistribution could dominate the international redistribution for generation 3 onward so that future generations in both the home and foreign countries could gain at the expense of some of those alive at the time of the debt issue. We could also conceive of a similar result occurring in a world where $z_{1}$ and $z_{2}$ were produced using reproducible capital and labour instead of land and labour, but such examples would require additional restrictions on technology to ensure stability.

Finally it should be pointed out that there is one type of technology, occasionally mentioned in the literature, which will leave foreigners completely unaffected by an increase in debt in the home country. This is the linear storage technology,

$$
y_{t}=w+\theta k_{t}
$$

where $k$ is reproducible and $\theta$ is a constant. In this case the price of capital is fixed in terms of consumption goods on the supply side so the debt issue does not generate any capital losses; and because the marginal product of capital is constant, there will not be a change in interest rates to alter foreign savings behaviour or real wages. Thus the debt issue will be fully internalized within the home country. 


\section{CONCLUDING REMARKS}

In this paper we have examined the effects of a deferral of taxes to future generations in both open and closed economies when factors of production are fixed in supply. Whether the economy is open or closed, the long-term interest rate rises montonically in response to the increase in debt, and the one-period interest rate may increase or decrease during the adjustment process. In the new equilibrium, the rate of interest will be greater and asset prices lower, the greater the amount of bonds outstanding. In the home country, the welfare of future generations will be reduced, as will the welfare of the old at the time of the tax deferral, but the young, whose taxes are deferred, will gain. In the foreign country the welfare of future generations will be increased, the welfare of the current old will be reduced, and the welfare of the current young will be increased or reduced depending upon whether the rate of interest rises or falls in the transition.

The anticipation of a future deficit will affect asset prices, interest rates and welfare. On the first date of anticipation the long-term rate of interest will rise (i.e. long-term asset prices will fall) and the short-term rate of interest will fall. From then until the date before the deficit the long rate will continue to rise monotonically and the short rate will fall monotonically. The long rate will continue to rise until a new stationary equilibrium is reached but the short rate may rise or fall on the date of the deficit. The welfare of all generations who are aware of the future deficit will be less than if no deficit had occurred. The generation that will be old at the time of the deficit will be better off than if the deficit had not been anticipated but all earlier generations will be worse off. 
Although the fiscal deficit may not generate a contemporaneous trade account deficit, it seems that the situations where it will not are quite limited. The home economy has to be big enough to have a significant impact on the short term interest rate, this rate has to fall, and the two countries have to be sufficiently different in tastes and technology. In all likelihood then, the debt issue will generate a contemporaneous trade deficit and capital account surplus. Of more interest is the fact that subsequent to the debt issue the home country will run a current account deficit for the lifetime of the initial young. This can be attributed to intragenerational distribution effects between agents at home and abroad.

We also contrasted our model with that of Persson's, where the capital stock is reproducible, by a technology in which it is a perfect substitute for consumption. That model suggests a greater commity of interest among future generations at home and abroad, and generations born prior to the period of the fiscal deficit are not affected by it. Having two outputs in our framework brings out some of the community of interest that transcends national boundaries and is similar to Persson's in this respect. However, in a model having both land and reproducible capital as inputs, many of our results remain: anticipated future deficits affect the current generations, the old at the time of the deficit suffer a welfare loss, and for some technologies it still is possible that future generations abroad gain at the expense of their cohorts at home.

In Appendix B we have examined the effect of country size on interest rates and welfare. Generally, the smaller the home country, the less will asset prices and interest rates change and, as a consequence, the less the decrease in welfare to the old and the greater the decrease to future 
generations. Also, the smaller the economy the less will generations anticipating the fiscal deficit be hurt. We also show circumstances where a myopic democratic country will increase its equilibrium level of government debt, the smaller the economy relative to the rest of the world. The rapid integration of world capital markets over the last few decades would be the real world counterpart of decreasing relative country size and could be part of any explanation for the increase in government peacetime deficits over that interval of tirne. 


\section{References}

Blanchard, 0. J., "Debt, Deficits and Finite Horizons," Journal of Political Economy V. 93 (1985), pp. 223-247.

Buchanan, J., "The Moral Dimension of Debt Financing," Economic Inquiry v. 23 (1985), pp. 1-7.

Calvo, G. A., "On the Indeterminancy of Interest Rates and Wages with Perfect Foresight," Journal of Economic Theory V. 19 (1978), pp. 321-337.

Diamond, P., "National Debt in a Neoclassical Growth Hodel" American Economic Review, V. 55 (1965), pp. 1126-1150.

Dornbusch, R., "Intergenerational and International Trade," Journal of International Economics, V. 18 (1985), pp. 123-139.

Frenkel, J. A. and A. Razin, "Fiscal Policies in the World Economy," Journal of Political Economy, V. 94 (1986), pp. 564-594.

Fried, J. "The Intergenerational Distribution of the Gains from Technical Change and From International Trade," Canadian Journal of Economics Vo1. 13, No. 1 (February 1980), pp. 65-81.

McCallum, B.T., "The Optimal Inflation Rate in an Overlapping-Genrations Economy with Land," Unpublished paper, June 1985.

Persson, T. "Deficits and Intergenerational Welfare in Open Economies," Journal of International Economics, 19 (1985), pp. 67-84. 


\section{Footnotes}

${ }^{1}$ other studies that have assumed a fixed factor of production in addition to labour in an overlapping generations framework include papers by Calvo (1978), Fried (1980) and McCallum (1985). Dornbusch, (1985) does not explicitly include a second fixed factor, but his treatment of government debt is such that land could easily be included. Our paper addresses some of the same questions as Dornbusch's but in a more general framework. Likewise the recent paper by Frenkel and Razin (1986) makes no reference to factors of production, but addresses some of the same questions as the present paper using the modified overlapping generations framework of Blanchard (1985). Although many of their positive results are similar to ours, our analysis also permits a welfare analysis. Furthermore, our model is not restricted to the case of additive logarithmic utility as is the Frenkel and Razin model.

2 Both Diamond and Persson implicitly assume a "putty-putty" model of capital. A "putty-clay" model with depreciation rates sufficiently low would also generate capital losses to the old and generate our particular welfare result. It is only the perfect substitutability of the capital and the consumption good that precludes capital gains and losses, not the reproducibility assumption.

${ }^{3}$ Calvo (1978) has shown that if saving is a decreasing function of the rate of interest then there exists a continuum of equilibrium paths that converge asymptotically to the stationary equilibrium without reaching it in finite time. We disregard all these equilibria and concentrate on the unique path that converges immediately.

${ }^{4}$ We assume that the government is able to commit itself to this future tax scheme, even though the scheme may not be time-consistent. 
${ }^{5}$ our experiment compares having a positive deficit with having no deficit. The results therefore do not necessarily apply to a comparison of a positive deficit with a smaller positive deficit. One reason for thinking that they might not apply to the latter comparison is that the positive relationship between the size of the deficit $I_{1}$ and the amount of debt outstanding after the deficit $b$, which we rely upon heavily, will not hold if the elasticity of $P_{1}$ with respect to $b$ is greater than unity.

6 By (3) and (8), $\frac{2}{d P_{1}}=\left(\frac{1}{P_{2}+\theta}\right) \frac{\partial x}{\partial R}+b \frac{\partial x}{\partial e}<\left(\frac{1}{P_{2}+\theta}\right)\left(\frac{\partial x}{\partial R}+\frac{\partial x}{\partial \theta}\right)<0$.

7We have already shown they consume more when old. To show that they consume more when young note that, from goods-market-clearing, (8) and $P_{0}>P_{1}$ : $\begin{aligned} c_{1}-c_{0} & =x_{0}-x_{1}=P_{0} k-P_{1} k>0 . \\ 8_{B y}(16) \text { and Roy's Lemma: } & \\ & \frac{d}{d b} V\left[R^{*}(b), w-\theta b\right]=V_{1} R^{*}(b)-\theta V_{2} \\ & =-v_{2}\left[x\left(R^{*}(b), w-\theta b\right) R^{*}(b)+\theta\right]<0 .\end{aligned}$

${ }^{9}$ For instance, our analysis suggest that the U.S. fiscal deficit would reduce the welfare of the entire voting public of Europe if the one period rate fell. If the Diamond/Persson model were relevant, only future European generations would suffer, and then to a lesser extent than future generations in the U.S. 
${ }^{10}$ From a comparison of $(10)$ and $(14)$ :

$R^{\prime}(0)-R^{*}(0)=\frac{(\partial \hat{c} / \partial e+\partial \hat{x} / \partial e) \lambda\left(\partial \hat{c} * / \partial R^{*}+\partial \hat{x}^{*} / \partial R^{*}\right)}{\left[\partial \hat{c} / \partial R^{*}+\partial \hat{x} / \partial R^{*}+\lambda\left(\partial \hat{c} * / \partial R^{*}+\partial \hat{x}^{*} / \partial R^{*}\right)\right]\left(\partial \hat{c} / \partial R^{*} \partial \hat{x} / \partial R^{*}\right)}<0$.

Since $R_{1}^{*}=R_{1}$, therefore for small enough $b R_{3}^{*}>R_{3}$ and, by (1), $P_{2}^{*}>P_{2}$.

${ }^{11}$ To prove these inequalities use (12) and $P_{0}^{*}>P_{1}^{*}$ to show that

$X_{0}>X_{1} \cdot$ From (3) it follows that $R_{0}^{*}<R_{1}^{*}$ which, with (17), implies that

$c_{-1}<\mathrm{C}_{0}$. By goods market clearing therefore $\mathrm{x}_{-1}>\mathrm{x}_{0} \cdot$ A repeated

application of (3) and (17) gives $R_{t}^{*}<\underset{t+1}{R^{*}}$ and $x_{t-1}>X_{t}, t<t<1$.

$x_{t-1}>X_{t}$ also implies, by (12), $\underset{t-1}{P^{*}}>\underset{t}{P^{*}}, \tau<t<1$.

$$
\begin{aligned}
& { }_{\text {Assume }} \mathrm{P}_{T}^{*}<\mathrm{P}^{*}(0) \text { for some } T=t<1 \text {. Then, by (12) } \\
& \mathrm{X}_{\mathrm{t}}<\hat{\mathrm{X}}\left(\mathrm{R}^{*}(0), w, w^{*} ; \lambda\right) \text {. }
\end{aligned}
$$

But then, if the deficit was first anticipated in period $t-1$ instead of period

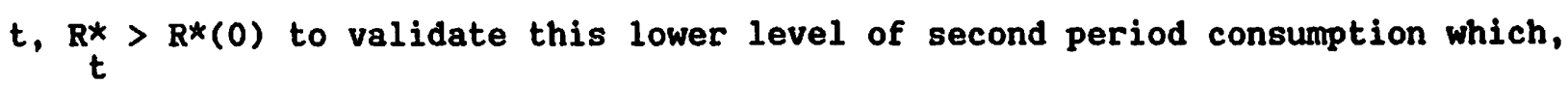
by (17) implies $\left.c_{t-1}>\hat{c}\left(R^{*}(0), w\right), w^{*} ; \lambda\right)$. By goods-market-clearing therefore $\left.x_{t-1}<\hat{X}_{\left(R^{*}\right.}^{*}(0), w, w^{*} ; \lambda\right)$ and, by $(12), P_{t-1}^{*}<P^{*}(0)$. Thus if $\mathrm{P}_{\tau}^{*}<\mathrm{P}^{*}(0)$ is true for $\tau=t<1$, it must be true for $\tau=t-1$. But we have already shown that it is true for $\tau=0$; therefore it is true for all $\tau<1$. It follows immediately that $R_{T+1}^{*}>R^{*}(0)$ for all $\tau<1$. ${ }^{13}$ Frenkel and Razin (1986) found that an anticpated future fiscal deficit unambiguously created a domestic current account deficit because in their modified overlapping-generations framework the anticipation has an 
important effect in the home country that is absent in the foreign country. specifically, no matter how far into the future the deficit will occur there are some people alive in the home country whose wealth will be increased by the tax cut. 


\section{Appendix A}

This appendix shows that for all b $\in[0, w / \theta)$ there exists a unique solution $R(b)$ to ( 10$)$ with $0<R<1$, and that this solution satisfies

(11). From (4):

(A.1) $\quad \partial D(R, b) / \partial R=\partial \hat{c} / \partial R+\partial \hat{x} / \partial R<0$ if $0<R<1$.

Therefore the solution to $(10)$, if it exists, is unique on $(0,1)$.

To prove existence note that $D(1, b)=w-\theta b-y<0$ (by the budget

constraint and the fact that $w<y$ ) and $\lim D(R, b)=\infty$ (by monotonicity).

$$
R \rightarrow 0
$$

The relationship between $R(b)$ and $b$ is:

(A.2) $\quad R^{\prime}(b)=\frac{-\partial D / \partial b}{\partial D / \partial R}=\left\{\frac{\theta}{\partial D / \partial R}\right\}\left\{\frac{\partial \hat{c}}{\partial e}+\frac{\partial \hat{x}}{\partial e}\right\}<0$.

(where the positivity of the second factor follows from (5)). From (4), (5),

(A.1) and (A.2):

(A.3) $R^{\prime}(b)=\theta\left[\frac{1+(1-R) \partial \hat{x} / \partial e}{-\hat{x}+(1-R) \partial \hat{x} / \partial R}\right]$

From (A.3) and (3):

(A.4) $R^{\prime}(b)>-\theta / \hat{x}$

Equation (11) follows from (A.2) and (A.4). 


\section{Appendix B}

In this appendix we examine the effect of country size on our results. The issues here are not central to those of the text, which examined the consequences on prices and welfare of a given change in government debt. Nonetheless, the closed economy results can be viewed as a special case for the open economy, where $\lambda=0$. For completeness, it is therefore of some interest to examine the consequences of placing the economy in a variety of environments differentiated only by different values of $\lambda$. We first examine the effects of $\lambda$ on asset prices.

The smaller the home country relative to the world economy the higher the new stationary equilibrium price will be from a given increase in bonds. The transition price of assets, $P_{1}^{\star}$, may increase or decrease with increased $\lambda$ although the conditions necessary for it to decrease are quite limited. To see these results note that the perfect foresight equilibrium can be characterized by the two equations.

$$
\begin{aligned}
& \text { (B.1) } w-\hat{c}\left(P_{1}^{*} /\left(P_{2}^{*}+\theta\right), w+P_{1}^{*} b\right)-P_{1} k+\lambda\left(w^{*}-\hat{c} *\left(P_{1}^{*} /\left(P_{2}^{*}+\theta\right), w^{*}\right)-P_{1} k^{*}\right)=0 \\
& \text { (B.2) } \hat{c}\left(P_{2}^{*} /\left(P_{2}^{*}+\theta\right), w-\theta b\right)+x\left(P_{2}^{*} /\left(\hat{P}_{2}^{*}+\theta\right), w-\theta b\right) \\
& +\lambda\left(\hat{c} *\left(P_{2}^{*} /\left(P_{2}^{*}+\theta\right), w^{*}\right)+x^{*}\left(P_{2}^{*} /\left(P_{2}^{*}+\theta\right), w^{*}\right)\right)-\left(y+\lambda y^{*}\right)=0
\end{aligned}
$$

Differentiating,

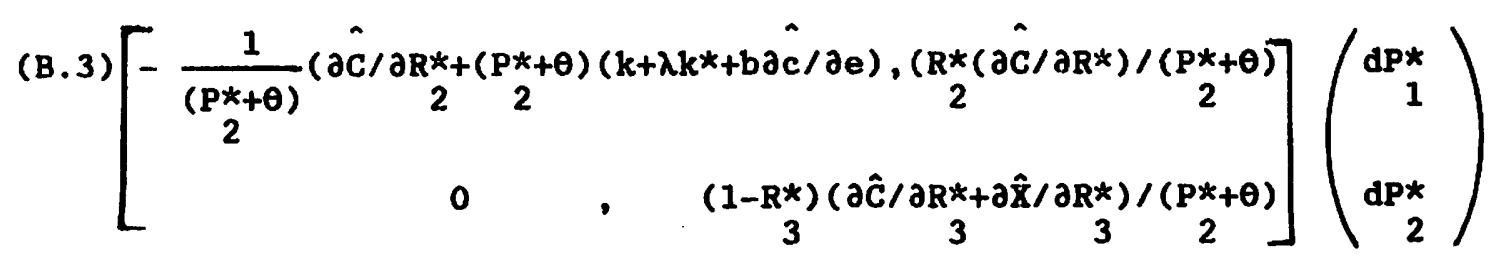




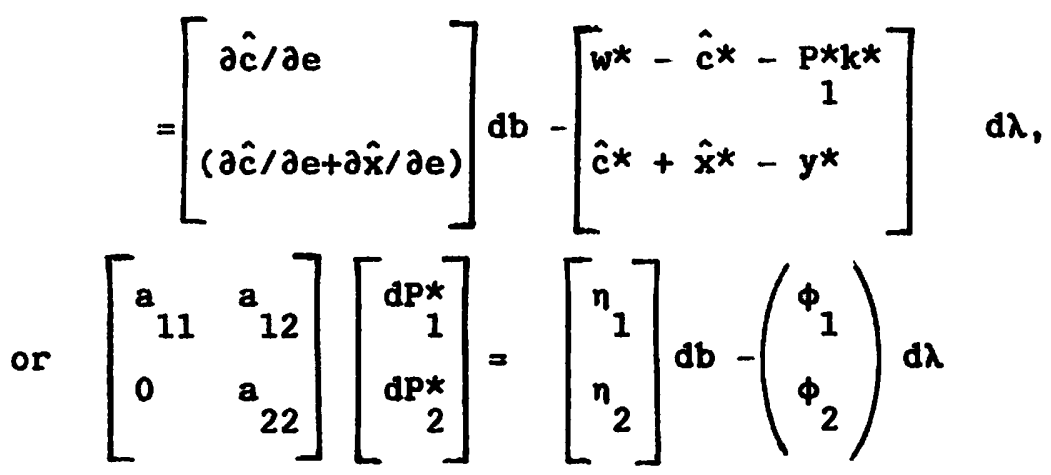

where

(B.4) $\begin{cases}a_{11},<0<a_{12} & \text { from (17), } \\ a_{22}<0 & \text { from (4), } \\ n_{1}, n_{2}>0 & \text { from normality, } \\ \Phi_{2}>0 & \text { from (4) and } R_{3}^{*}<R_{2}^{*} .\end{cases}$

Define $\Delta^{*} \equiv a_{11} a_{22}$ which is positive from (B.4).

Using Kramer's rule, from (B.4):

(B.5) $\partial \mathrm{P}_{2}^{*} / \partial \lambda=-\Phi_{2} \mathrm{a}_{11} / \mathrm{A}^{*}>0$.

It also follows that the effect of the deficit on the long term rate of interest is less the smaller the home country relative to the world.

To determine the effect of $\lambda$ on $P_{1}^{*}$ we need to know the sign of $\phi_{1}$, which is equal to $(1 / \lambda)$ times the period 1 capital account of the home country. The condition necessary for $P_{1}^{*}$ to be an increasing function of $\lambda$ is: (B.6) $\partial P_{1}^{*} / \partial \lambda=\left[-\Phi_{1} a_{22}+\phi_{2} a_{12}\right\} / \Delta^{*}$

$=R_{2}^{*}\left[S \underset{3}{\left[\partial \hat{C} / \partial R^{*}\right.}+\underset{3}{\left.\partial \hat{X} / \partial R^{*}\right]}+s_{3} \partial \hat{C} / \partial R^{*}\right] / \lambda\left(P^{*}+\theta\right) \Delta^{*}>0$,

where $s_{t}$ is the service account of the home country in period $t$. If $s_{2}$ is negative, i.e. there was a capital inflow into the home country in period 1 , then this condition is met. If the home country actually ran a capital surplus then the result is ambiguous. We argued in the text that there are a wide variety of situations where $s_{2}$ would be negative and that very specific 
conditions must be assumed if $s_{2}$ is to be positive. In particular to have $s_{2}$ be positive, consumption when young must be insensitive to changes in endowments and interest rates in the home country, but be sensitive with respect to interest rates abroad, the home country cannot be "too small", and in autarky, the deficit would have caused the interest rate to fall in period 1 .

We are unable to sign $\partial R_{2}^{*} / \partial \lambda$. This can be seen most intuitively by noting that from (B.3) it can be shown that:

$$
\text { (B.7) } \operatorname{Lim}_{\lambda \rightarrow \infty} \partial P_{1}^{*} / \partial b=\lim _{\lambda \rightarrow \infty} \partial P_{2}^{*} / \partial b=0 \text {, }
$$

and therefore

$$
\operatorname{Lim}_{\lambda \rightarrow \infty} R_{2}^{*}=R_{1}^{*}
$$

Because for $\lambda<\infty$, preferences can be such that $R_{2}^{*}$ may be greater or less than $R_{1}^{*}$, therefore with increasing $\lambda, R_{2}^{*}$ can approach $R_{1}^{*}$ from either above or below. Note further that this implies that even with a configuration of preferences that cause $\partial \mathrm{P}_{1}^{*} / \partial \lambda$ to be negative for some $\lambda$, such a relationship, by (B.7) and $\mathrm{P}_{0}^{*}>\mathrm{P}_{1}^{*}>\mathrm{P}_{2}^{*}$, cannot hold for all values of $\lambda$. Because asset prices and interest factors change with changes in the size of the economy relative to the rest of the world, $\lambda$ will also affect the level of welfare across generations in the home country. For small amounts of debt, the smaller relatively is the home country, the greater the harm to future generations for a given increase in debt. This is because the effect on their welfare when $b=0$ is:

$$
-V_{2}\left(R^{*}(0), w\right)\left[\hat{x}\left(R^{*}(0), w\right) R^{* 1}(0)+\theta\right]
$$

and $R^{*}(0)$ is an increasing function of $\lambda$. The smaller the country the less the opportunity for its future generations to be compensated for their increased taxes by an increase in the rate of interest. 
For the most reasonable case, where $\partial \mathrm{P}_{1}^{*} / \partial \lambda>0$, generation 0 loses by less the smaller is the economy relative to the rest of the world because, the greater is $\lambda$ the less the capital loss on their asset holdings from the increase in debt. By extension the cost is also less for earlier generations who anticipated the fiscal deficit if the home country is smaller. This is because, if $P^{\star}$ does not fall by as much, $R^{*}$ need not 1 1 increase by as much to reduce second period demand over the entire path of $R^{*}, \tau<t \leq 1$ t

The welfare of generation 1 in the home country may increase or decrease with increased $\lambda$. For the case of $\partial P_{1}^{*} / \partial \lambda>0$, the size of the transfer, $P_{1}^{*} b$, increases with $\lambda$, improving welfare. On the other hand, increases in $\lambda$ may reduce the rate of interest, reducing that generation's welfare by more than enough to offset the increase generated by the increased real value of the transfer. If, however, $\partial R_{2}^{*} / \partial \lambda<0$, then, in this case, generation 1 unambiguously gain the greater is $\lambda$.

A current issue of political economy that our model has the potential to address is the question of why government debt has grown so rapidly in recent years. Buchanan (1985) has argued that one of the major reasons for the explosion of peacetime government deficits has been the breakdown in "moral constraints" upon the government and the voting public. Our model suggests that a more mundane constraint has been removed, namely constraints on international capital flows. Removal of this constraint, which we interpret as an increase in $\lambda$, provides voters in the home country additional groups who could bear the cost of the debt issue and thereby enhance the welfare 
gains of the current generations in the home country. Thus, the equilibrium level of debt will be greater, the smaller is the home country relative to the rest of the world.

To see that this possibility exists suppose that a myopic, democratic country has a social welfare function at any date $t$ of

$$
\Omega_{t}=\alpha^{0} u\left(c_{t-1}, x_{t}\right)+\alpha^{y} u\left(c_{t}, x_{t+1}\right)
$$

where $\alpha^{0}+\alpha^{y}=1, \alpha^{0}, \alpha^{y}>0$. Let the economy be autarkic and in $a$ stationary equilibrium that has maximized $\Omega$ with the optimal level of

debt, $\bar{b}$. The decision problem generating this optimum is to maximize over $T_{t}$ : (B.8) $\Omega_{t}=\alpha^{0} u\left(\underline{c},\left(P_{t}+\theta\right)(k+\bar{b})\right)+\alpha^{y} v\left(R_{t+1}, w+T t\right)$ subject to (9), where $T t=-\theta_{b}^{-}+D t$ and $D t$ is the deficit in period $t$. Assume an interior solution, $\bar{b}<w / \theta$, is achieved at $t=0$. Then the equilibrium for $t=1$ is characterized by the first order condition

$$
\partial \Omega_{1} / \partial T_{1}=\alpha^{0}\left(k+b^{-}\right) u_{x} \partial P_{1} / \partial T_{1}+\alpha^{y}\left[V_{1} \partial R_{2} / \partial T_{1}+V_{2}\right]=0
$$

Using Roy's lemma and $\mathrm{u}_{x}=\mathrm{RV}_{2}$, this can be restated as

(B.9) $\partial \Omega_{1} / \partial T_{1}=V_{2}\left[\alpha^{0}(k+\bar{b}) \bar{R} \partial P_{1} / \partial T_{1}+\alpha^{y}\left(1-\hat{x} \partial R_{2} / \partial T_{1}\right)\right]=0$

where $\bar{R}=R(\bar{b})$. Because $\partial P_{1} / \partial T_{1}<0$, in the autarkic equilibrium, any

social gains to the young from an additional tax deferral will be just offset by the social losses to the old. 
At date $t=1$ open this economy, having $\bar{b}$ bonds outstanding, to a world of $\lambda$ other agents having arbitrary tastes and endowments that has, in its equilibrium, the identical interest rate factor, $\bar{R}$. If $\lambda=\infty$, then, because $\lim _{\lambda \rightarrow \infty} P_{2}^{*}=P_{0}^{*},(B .9)$ reduces to $\partial \Omega_{1} / \partial T_{1}=v_{2} a^{y}>0$ implying the optimum level of outstanding debt is $w / \theta$, greater than $\bar{b}$. Thus there exists at least some $\lambda$, sufficiently large, that causes the optimal quantity of debt outstanding in the open economy to be greater than the optimal amount of autarky.

As a second example suppose a world with identical individuals having identical technology and per capita endowments. Let preferences be $10 \mathrm{~g} 1$ inear: (B.10) $u_{t}=\ln c_{t}+\beta \ln x_{t+1}$. In this case demands for first and second period consumption are: (B.11) $\hat{c}_{t}=e_{t} /(1+\beta)$ and $\hat{x}_{t+1}=\beta e_{t} /(1+\beta) R_{t+1}$. For the home country in autarky, it can be shown that (B.12) $P(\bar{b})=\beta(w-\overline{\theta b}) /(1+\beta)(k+\bar{b})$. For a fiscal deficit in period 1 , given $\bar{b}$ bonds outstanding, (B.13) $P_{1}=\left[\beta(w-\theta \bar{b})-D_{1}\right] /(1+\beta)(k+\bar{b})=P(\bar{b})-D_{1} /(1+\beta)(k+\bar{b})$. Substituting (B.10) - (B.13) into the social welfare function (B.8) and differentiating gives the condition for the optimal level of $b$ for the closed economy : 
(B.14) $\partial \Omega / \partial T_{1}=\beta\left(\alpha^{0}-\alpha^{y}\right) \frac{\partial_{1} / \partial T}{P_{1}}+\frac{\alpha^{y}(1+\beta)}{e}+\alpha^{y} \frac{\partial P(b) / \partial T}{(P(b)+\theta)}=0$

where $e=w-\theta_{b}+D_{1}$. For sufficiently large $a^{0}$ an interior solution for

$\bar{b}$ exist, since both $\partial P_{1} / \partial T_{1}$ and $\partial P(b) / \partial T_{1}$ are negative.

For the rest of the world, having population $\lambda$, it follows that, if it is to have the same rate of interest, it must also have the same per capita quantity of land and bonds outstanding. Given the same land, the same social welfare function for the rest of the world is necessary to generate the same per capita quantity of bonds. Suppose this is the case so that the world has a population $\lambda+1$ members of each generation with identical preferences and in identical circumstances. Then, for the world economy, $P *(\bar{b})$ is the same as in (B.12),

$$
\begin{aligned}
& P_{1}^{*}=\left[\beta(w-\theta \bar{b})-D_{1} /(1+\lambda)\right] /(1+\beta)(k+\bar{b}) \text {, and } \\
& P^{*}\left(\bar{b}+b^{\prime}\right)=\beta\left(w-\theta \bar{b}-\theta b^{\prime} /(1+\lambda)\right) /(1+\beta)\left(k+\bar{b}+b^{\prime} /(1+\lambda)\right)
\end{aligned}
$$

where $b^{\prime}=D_{1} / P *$. Now define a new transfer, $\tilde{T} \equiv-\theta b+(1+\lambda) D_{1}$. Then

(B.15) $\underset{1}{\partial P * / \partial T}=\partial P_{1} / \partial T_{1}$ and $\partial P *(b) / \partial \tilde{T}=\partial P(b) / \partial T_{1} \cdot$

Let $\tilde{\Omega}$ represent the home country's social welfare function when the economy is open. Then, using (B.14) and (B.15), 
$\partial \tilde{\Omega} / \partial \tilde{T}=\partial \Omega / \partial T_{1}+\alpha^{y}(1+\beta) \lambda(w-\theta \bar{b}) / e\left(e+\lambda D_{1}\right)>0$,

where $e=w-\theta_{b}+D_{1}$. Thus, for all $\lambda>0$ there is an incentive to issue more debt if the economy is open than if it is closed. By extension, the smaller is the economy relative to the world, the larger will be its stationary equilibrium level of per capita debt.

It should also be noted that the rest of the world is in a symetrical position relative to the home country, and they too will have an incentive to defer taxes. If the rest of the world is large (small) relative to the home country, its equilibrium level of per capita debt will be smaller (larger) than that of the home country, but both countries will increase their debt. Because debt increases with the opening of trade, future generations will bear an even larger burden of taxes to service that debt.

Finally, we would point out that, in Persson's model, the incentive to increase the equilibrium debt with increases in $\lambda$ does not exist to the same extent. This is because there is not generally an opportunity to extract rents from non-residents since their welfare moves in the same direction as their cohorts in the home country. Indeed, given that neither young nor old lose from an increase in debt, the only reason the equilibrium debt would increase for the democratic home country is if foreign investment occurs. This would increase the ability of future generations to bear a larger tax load and current generations oblige by deferring taxes accordingly. 
8401C Harrison, Glenn w. and Manning, Richard. BEST APPROXIMATE AGGREGATION OF INPUT-OUTPUT SYSTEMS.

8402C Parkin, Michael. CORE INFLATION: A REVIEN ESSAY.

8403C Blomquist, Ảke, and MCMahon, Gary. SIMULATING COMMERICAL POLICY IN A SMALI, OPEN DUAL ECONOMY WITH URBAN UNEMPLOYMENT: A GENERAL EQUILIBRIUM APPROACH.

8404C Wonnacott, Ronald. THE THEORY OF TRADE DISCRIMINATION: THE MIRROR IMAGE OF VINERIAN PREFERENCE THEORY?

8405C Whalley, John. IMPACTS OF A 50\% TARIFF REDUCTION IN AN EIGET-REGION GLOBAL TRADE MODEL.

8406C Harrison, Glenn W. A GENERAL EQUILIBRIUM ANALYSIS OF TARIFT REDUCTIONS.

8407C Horstmann, Ignatius and Markusen, James R. STRATEGIC INVESTMENTS AND THE DEVELOPMENT OF MULTINATIORALS.

8408C Gregory, Allan W. and McCurdy, Thomas H. TESTING THE UNBIASEDNESS HYPOTHESIS IN THE FORWARD FOREIGN EXCHANGE MARKET: A SPECIFICATION ANALYSIS.

$8409 \mathrm{C} J o n e s$, Ronald $\mathrm{W}$, and Klerzkowsk1, Henryk. NEIGHBORHOOD PRODUCTION STRUCTURES WITH APPLICATIONS TO THE THEORY OF INTERNATIONAL TRADE.

$8410 \mathrm{C}$ Weller, Paul and Yano, Makoto. THE ROLE OR FUTURES MARKETS IN INTERNATIONAL TRADE: A GENERAL EỌUILIBRIUM APPROACH.

$8411 \mathrm{C}$ Brecher, Richard A. and Bhagwat1, Jagdish N. VOLUNTARY EXPORT RESTRICTIONS VERSUS IMPORT RESTRICTIONS: A WELFARE-THEORETIC COMPARISON.

8412C Eth1er, Wilfred J. ILLEGAL IMMICRATION.

8413C Eaton, Jonathon and Gene M. Grossman. OPTIMAL TRADE AND INDUSTRIAL POLICY UNDER OLIGOPOLY.

8414C Hooton, Ian. PREFERENTIAL TRADING AGREEMENTS - A 3xn MODEL.

8415C Park1n, Michael. DISCRIMINATING BETWEEN KEYNESIAN AND CLASSICAL THEORIES OF THE BUSINESS CYCLE; JAPAN 1967-1982

8416C Deardorff, Alan V. FIRless FIRwoes: HOW PREFERENCES CAN INTERFERE WITH THE THEOREYS OF INTERNATIONAL TRADE.

8417C Greenwood, Jeremy. NONTRADED GOODS, THE TRADE BALANCE, AND THE BALANCE OF PAYIENTS. 
8418C Blomqvist, Ake and Sharif Mohammad. CONTROLS; CORRUPTION, AND COMPETITIVE RENT-SEEKING IN LDCS.

8419C Grossman, Herschel I. POLICY, RATIONAL EXPECTATIONS, AND POSITIVE ECONOMIC ANALYSIS.

$8420 \mathrm{C}$ Garber, Peter M. and Robert G. King. DEEP STRUCTURAL EXCAVATION? A CRITIOUUE OF EULER EQUATION METHODS.

$8421 \mathrm{C}$ Barro, Robert J. THE BEHAVIOR OF U.S. DEFICITS.

8422C Persson, Torsten and Lars E.0. Svensson. INTERNATIONAL BORRONING AND TIME-CONSISTENT FISCAL POLICY.

8423C Obstfeld Maurice. CAPrtal controls, THE DUAL EXCHANGE RATE, AND DEVALUATION.

8424C Kuhn, Peter. UNION PRODUCTIVITY EFFECTS AND ECONOMIC EFFICIENCY.

3425C Hamilton, Bob and John Whalley. TAX TREATMENT OF HOUSING IN A DYNAMIC SEOUUENCED GENERAL ENUILIBRIUM MODEL.

$\because 426 \mathrm{C}$ Hamilton, Bob, Sharif Mohammad, and John Whalley. RENT SEEKING AND THE NORTH-SOUTH TERMS OF TRADE.

8427C Adams, Charles and Jeremy Greenwood. DUAL EXCHANCE RATE SYSTEMS AND CAPITAL CONTROLS: AN INVESTIGATION.

3428 Loh, Choon Cheong and Michael R. Veall. A NOTE ON SOCIAL SECURITY AND PRIVATE SAVINGS IN SINGAPORE.

8429 Whalley, John. RFGRESSION OR PROGRESSION: THE TAYING OUESTION OF INCIDENCE ANALYSIS.

3430 Kuhn, Peter. WAGES, EFFORT, AND INCENTIVE-COMPATIBILITY IN LIFE-CYCLE EMPLOYMENT CONTRACTS.

8431 Greenwood, Jereny and Kent P. Kimbrough. AN INVESTIGATION IN THE THEORY OF FOREICN EXCHANGE CONTROLS.

8432 Greenwood, Jeremy and Kent. P. Kimbrough. CAPITAL CONTROLS AND THE INTERNATIONAL TRANSMISSION OF FISCAL POLICY.

8433 : Nguyen, Trien Trien and John Whalley. EnUILIBRIUM UNDER PRICE CONTROLS WITH ENDOGENOUS TRANSACTIONS COSTS.

8434 Adams, Charles and Russell S. Boyer. EFFICIENCY AND A SIMPLE MODEL OF EXCHANGE RATE DETERMINATION. 
8435 Kuhn, Peter. UNIONS, ENTREPRENEURSHIP, AND EFFICIENCY.

8436 Hercowttz, Zvi and Efraim Sadka. ON OPTIMAL CURRENCY. SUBSTITUTION POLICY AND PUBLIC PINANCE.

8437 Lenjosek, Gordon and John Whalley, POLICY EVALUATION IN A SMALL OPEN PRICE TAKING ECONOMY: CANADIAN ENERGY POLICIES.

8438 Aschauer, David and Jeremy Greenwood. MACROECONOMIC EFFECTS OF FISCAL POLICY.

8439C Hercowitz, Zv1. ON THE DETERMINATION OF THE EXTERNAL DEBT: THE CASE OF ISRAEL.

8440C Stern, Robert M. GLOBAL DIMENSIONS AND DETERMINANTS OF INTFRNATIONAL TRADE AND INVESTMENT IN SERVICES.

8441C Deardorff, Alan V. COMPARATIVE ADVANTAGE AND INTERNATIONAL TRADE AND INVESTMENT IN SERVICES.

8442C Daly, Donald J. TECHNOLOGY TRANSFER AND CANADA'S COMPETITIVE PERFORMANCE.

8443C Grey, Rodney de C. NEGOTIATING ABOUT TRADE AND INVESTMENT IN SERVICES.

8444C Grossman, Gene $M$. and Carl Shapiro. NORMATIVE ISSUES RAISED BY INTERNATIONAL TRADE IN TECHNOLOGY SERVICES.

3445C Chant, John F. THE CANADIAN TREATMENT OF FOREIGN BANKS: A CASE STUDY IN THE WORKINGS OF THE NATIONAL TREATMENT APPROACH.

8446C Aronson, Jonathan D. and Peter F. Cowhey. COMPUTER, DATA PROCESSING, AND COMMUNICATION SERVICES.

8447C Feketakuty, Geza. - NEGOTIATING STRATEGIES FOR LIBERALIZING TRADE AND INVESTMIENT IN SERVICES.

8448C Harrison, Glenn, W. and E.E. Rutstrom. THE EFFECT OF MANUTACTURING SECTOR PROTECTION ON ASEAN AND AUSTRALIA: A GENERAL ENUUILIBRIUM ANALYSIS. 
8501C Greenwood, Jeremy and Kent P. Kimbrough. FOREIGN EXCHANGE CONTROLS IN A BLACK MARKET ECONOMY.

8502C Horstmann, Ignatius and James R. Markusen. UP YOUR AVERAGE COST CURVE: INEFFICIENT ENTRY AND THE NEW PROTECTIONISM.

$8503 C$ Gregory, Allan $W$. TESTING INTEREST RATE PARITY AND RATIONAL EXPECTATIONS FOR CANADA AND THE UNITED STATES.

8504C Kuhn, Peter and Ian Hooton. INTERNATIONAL FACTOR MOVEMENTS IN THE PRESENCE OF A FIXED FACTOR.

8505C Wong, Kar-yiu. GAINS FROM GOODS TRADE AND FACTOR MOBILITY.

8506C Weller, Paul and Makoto Yano. FUTURES MARKETS, REAL INCOME, AND SPOT PRICE VARIABIIITY: A GENERAL EỌDIIIBRIUM APPROACH.

8507C Diewert, H.E. THE EFPECTS OF AN INNOVATION: A TRADE THEORY APPROACH.

8508C Ethier, Wilfred J. POREIGN DIRECT INVESTMENT AND THE MULTINATIONAL FIRM.

8509C Dinopoulos, Elias. INSIDE THE BLACK BOX: (IN) TANGIBLE ASSETS, INTRA-INDUSTRY INVESTMENT AND TRADE.

8510C Jones, Richard, John Whalley, and Randall Higle. REGIONAL IMPACTS OF TARIFFS IN CANADA: PRELIMINARY RESULTS FROM A SMALI DIMENSIONAI NUMERICAL GENERAL EOUUILIBRIUM MODEL.

8511C Whalley, John. HIDDEN CHALLENGES IN RECENT APPLIED GENERAL EQQUIL IBRIUM EXERCISES.

8512C Smith, Bruce. SOME COLONIAL EVIDENCE ON TWO THEORIES OF MONEY: MARYLAND AND THE CAROLINAS.

3513C Grossman, S.J., A. Melino, and R.J. Shiller. ESTIMATING THE CONTINUOUS TIME CONSUMPTION BASED ASSET PRICING MODEL.

8514C Romer, Paul R. TAX EFFECTS AND TRANSACTION COSTS FOR SHORT TERM MARKET DISCOUNT BONDS. .

8515C McCallum, Bennett T. ON CONSEOUUENCES AND CRITJCISMS OF MONETARY TARGETING.

8516C Dinopoulos, Elias and Ian Wooton. A NORTH-SOUTH MODEL OF INTERNATIONAL JUSTICE.

8517C Huffman, Gregory W. A DYNAMIC EQUILIBRIUM MODEL OF ASSET PRICES AND TRANSACTION VOLUME.

8518C Huffman, Gregory W. AN ALTERNATIVE VIEW OF OPTIMAL SEIGNIORAGE.

8519C Huffman, Gregory W. ASSET PRICING WITH HETERGENEOUS ASSETS. 


\section{$\underline{1985}$}

8520C Hercowitz, Zv1. THE REAL INTEREST RATE AND AGGREGATE SUPPLY.

8521C Davies, James and Michael Hoy. COMPARING INCOME DISTRIBUTIONS UNDER AVERSION TO DOWNSIDE INEQUALITY.

8522C Nguyen, Trien T. and John Whalley. COEXISTENCE OF EQUILIBRIA ON BLACK AND WHITE MARKETS.

8523C Clarete, Ramon and John Whalley. INTERACTIONS BETWEEN TRADE POLICIES AND DOMESTIC DISTORTIONS: THE PHILIPPINE CASE.

8524C Hamilton, Bob, Sharif Mohammad, and John Whalley. APPLIED GENERAL EQUILIBRIUM ANALYSIS AND PERSPECTIVES ON GROWTH PERFORMANCE.

8525C Huffman, Gregory $W$. THE LAGGED EFFECTS OF POLICY ON THE PRICE LEVEL.

8526C Laidler, David. FISCAL DEFICITS AND INTERNATIONAL MONETARY INST ITUTIONS.

8527C Goodfriend, Marvin. MONETARY MYSTIQUE: SECRECY AND CENTRAL BANKING.

8528C Nguyen, Trien $T$. and John Whalley. GENERAL EQUILIBRIUM ANALYSIS OF PRICE CONTROLS A TWO-SECTOR COMPUTATIONAL APPROACH.

8529C Heckman, James J. and V. Joseph Hotz. AN INVESTIGATION OF THE LABOR MARKET EARNINGS OF PANAMANIAN MALES: EVALUATING SOURCES OF INEQUALITY.

8530C Greenwood, Jeremy and Gregory W. Huffman. A DYNAMIC EQUILIBRIUM MODEL OF INFLATION AND UNEMPLOYMENT.

8531C Freeman, Scott. INSIDE MONEY, MONETARY CONTRACTIONS, AND WELFARE.

8532C Paderanga, Cayetano Jr. and Ian Wooton. A POSITIVE VIEW OF INFANT INDUSTRIES.

8533C St-Hilaire, France and John Whalley. A MICROCONSISTENT DATA SET FOR CANADA FOR USE IN REGIONAL GENERAL EQUILIBRIUM POLICY ANALYSIS.

8534C Whalley, John. OPERATIONALIZING WALRAS: EXPERIENCE WITH RECENT APPLIED GENERAL EQUILIBRIUM TAX MODELS.

8535C Melvin, James R. THE GENERAL NON-EQUIVALENCE OF TARIFFS AND IMPORT QUOTAS. 
8601C Greenwood, Jeremy and R. Preston McAfee. EXTERNALITIES AND ASYMMETRIC INFORMATION.

8602C Dinopoulos, Elias and Mordecha1 E. Kreinin. IMPORT QQUOTAS AND VERS: A COMPARATIVE ANALYSIS IN A THREE-COUNTRY FRAMBWORK.

8603C Clarete, Ramon and John Whalley. COMPARING THE MARGINAL WELFARE COSTS OF COMMODITY AND TRADE TAXES.

8604C Wigle, Randy. CANADIAN TRADE LIBERALIZATION: SCALE ECONOHIES IN A GLOBAL CONTEXT.

8605C Parkin, Michael. DOMESTIC MONETARY INSTITUTIONS AND FISCAL DEFICITS.

8606C Dinopoulos, Elias and Ian Wooton. INTERNATIONAL TRADE AND THE ACQUISITION OF SKILLS.

8607C Kawasaki, Seilchi and John McMillan. THE DESIGN OF CONTRACTS: EVIDENCE FROM JAPANESE SUBCONTRACTING.

8608C Williamson, stephen D. LIQUIDITY, BANKING, AND BANK FAILURES.

8609C Grossman, Gene M. and Carl Shapiro. COUNTERFEIT-PRODUCT TRADE.

8610C Deardorff, Alan V. WHY DO GOVERNMENTS PREFER NONTARIFF BARRIERS?

8611C Horstmann, Ignatius and James R. Markusen. LICENSING VERSUS DIRECT INVESTMENT: A MODEL OF INTERNALIZATION BY THE MULTINATIONAL ENTERPRISE.

8612C Thursby, Jerry G. and Marie C. Thursby. BILATERAL TRADE FLOWS, THE LINDER HYPOTHESIS, AND EXCHANGE RISK.

8613C Clarete, Ramon and John Whalley. EQUIIIBRIUM IN THE PRESENCE OF FOREIGN EXCHANGE PREMIA.

8614C Wooton, Ian. TOWARDS A COMMON MARKET: FACTOR MOBILITY IN A CUSTOMS UNION.

8615C St-Hilaire, France and John Whalley. SOME ESTIMATES OF TRADE FLOWS IN BANKING SERVICES.

8616C Evenson, Robert E. and Cayetano Paderanga Jr. RURAL LABOUR MARKETS, TRANSACTION COST AND FERTILITY.

8617C Frled, Joel and Peter Howitt. FISCAL DEFICITS, INTERNATIONAL TRADE AND WELFARE.

8618C Trela, Irene, John Whalley, and Randy Wigle. INTERNATIONAL TRADE IN AGRICULTURE: DOMESTIC POLICIES, TRADE CONFLICTS, AND NEGOTIATING OPTIONS. 